Table 1 Percentage of female and male first author of rheumatological guidelines stratified by disease

\begin{tabular}{lll}
\hline Disease & Female (\%) & Male (\%) \\
\hline Osteoarthritis $(n=34)$ & 26.5 & 73.5 \\
\hline Rheumatoid arthritis $(n=96)$ & 18.8 & 81.2 \\
\hline Fibromyalgia $(n=30)$ & 20 & 80 \\
\hline Lupus erythematosus $(n=29)$ & 34.5 & 65.5 \\
\hline Psoriatic arthritis and spondyloarthritis $(n=73)$ & 23.3 & 76.7 \\
\hline Sjogren syndrome $(n=5)$ & 40 & 60 \\
\hline Gout $(n=19)$ & 10.5 & 89.5 \\
\hline Systemic sclerosis $(n=18)$ & 16.7 & 83.3 \\
\hline Polymyalgia and giant cells' arteritis $(n=12)$ & 0 & 100 \\
\hline Osteoporosis $(n=26)$ & 30.8 & 69.2 \\
\hline ANCA associated vasculitides $(n=14)$ & 21.4 & 78.6 \\
\hline Polymyositis and dermatomyositis $(n=6)$ & 50 & 50 \\
\hline Behcet's disease $(n=4)$ & 25 & 75 \\
\hline
\end{tabular}

high impact medical journals. ${ }^{12}$ Nevertheless, the trend seems to be improving over the last 20 years but it has plateaued in recent years. ${ }^{3}$ It is not known if a comparable under-representation occurs also in rheumatological guidelines. We have conducted a bibliometric analysis to evaluate the representation of female authors in rheumatological guidelines and recommendations over a period of time between 2004 and 2019. We searched PubMed for guidelines and recommendations published in English in the rheumatological field from 1 January 2004 to 1 January 2019. We included all guidelines and recommendations, published by rheumatologists and rheumatology health-related professionals in rheumatology journals. Gender of each first author (man or woman) was determined by use of a minimum of two resources (ie, author's name and an internet search to identify the author's photograph or gender pronoun).

We found 366 guidelines and recommendations published between 2004 and 2019 (table 1: stratified by disease). Overall, the proportion of female first authors was $32.0 \%$ (95\% CI $28.0 \%$ to $35.0 \%$ ). After stratification by year of publication the percentage of female first authors was lower in past years compared with recent years. We found an association between year of publication and the proportion of female first author (figure 1). Indeed, the percentage of female first author seemed

\section{Gender disparity in authorship of guidelines and recommendations in rheumatology}

Women are generally less represented as first author among original medical researches and clinical guidelines. Indeed, women are first authors in only $30 \%$ of clinical guidelines published in

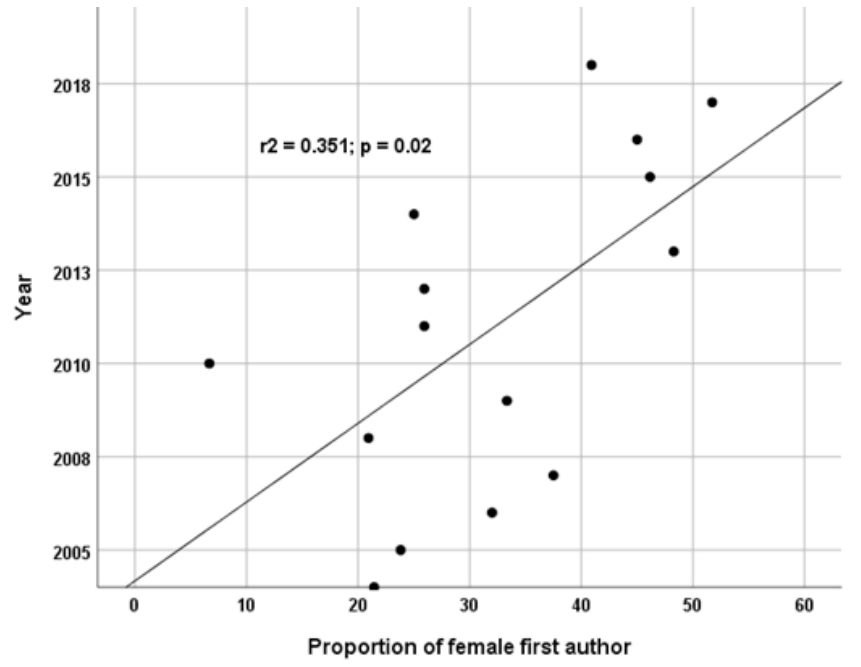

Figure 1 Association between year of publication and proportion of female first author. 


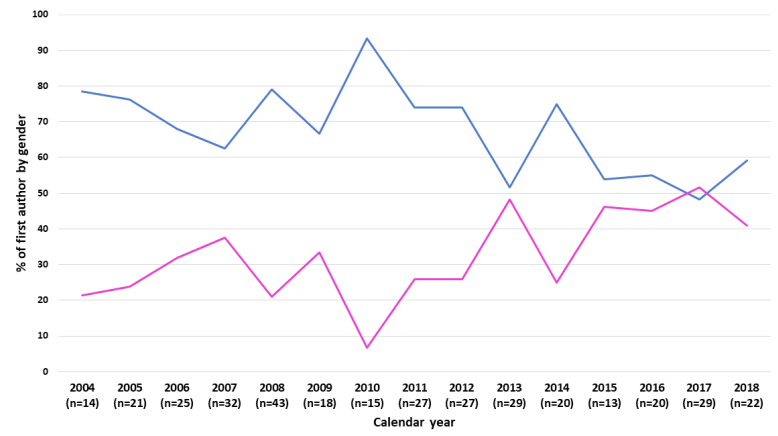

Figure 2 Temporal trend of the proportion of first author gender from 2004 to 2019 (male in blue, female in pink).

to substantially increase over the last 15 years (figure 2). We analysed the proportion of female first author stratified by disease topic (table 1). The large majority of guidelines and recommendations were published on rheumatoid arthritis $(n=96)$ followed by psoriatic arthritis/spondyloarthritis $(n=73)$ and osteoarthritis $(n=34)$. With the only exception of polymyositis and dermatomyositis $(50 \% / 50 \%)$ all the authorships were dominated by males.

Overall, we found a large prevalence of male as first authors of guidelines and recommendations in the rheumatological field published between January 2004 and January 2019. The EULAR Task Force on Gender Equity in Academic Rheumatology has been recently established, making an important first step toward gender equity in the authorship of guidelines in the rheumatological fields. Indeed, in the last 15 years we have witnessed an increase in female representativeness. Notwithstanding, efforts should be made to improve the representation of female authors nationally and internationally.

\section{Giovanni Adami ๑ , ${ }^{1}$ Camilla Benini, ${ }^{1}$ Elisabetta Vantaggiato, ${ }^{1}$ Denise Rotta, ${ }^{1}$ Ombretta Viapiana, ${ }^{1}$ Davide Gatti, ${ }^{1}$ Maurizio Rossini $\odot$, Annamaria lagnocco ${ }^{2}$}

${ }^{1}$ Rheumatology Unit, Department of Medicine, University of Verona, Verona, Italy ${ }^{2}$ Rheumatology Unit, University of Torino, Torino, Italy

Correspondence to Dr Giovanni Adami, Rheumatology Unit, Department of Medicine, University of Verona, Verona 37134, Italy; adami.g@yahoo.com

\section{Handling editor Josef S Smolen}

Contributors All the authors contributed equally to the design of the research, to the analysis of the results and to the writing of the manuscript.

Funding The authors have not declared a specific grant for this research from any funding agency in the public, commercial or not-for-profit sectors.

Competing interests None declared.

Patient and public involvement Patients and/or the public were not involved in the design, or conduct, or reporting, or dissemination plans of this research.

Patient consent for publication Not required.

Provenance and peer review Not commissioned; externally peer reviewed.

\section{(อ) OPEN ACCESS}

Open access This is an open access article distributed in accordance with the Creative Commons Attribution Non Commercial (CC BY-NC 4.0) license, which permits others to distribute, remix, adapt, build upon this work non-commercially, and license their derivative works on different terms, provided the original work is properly cited, appropriate credit is given, any changes made indicated, and the use is non-commercial. See: http://creativecommons.org/licenses/by-nc/4.0/.

(C) Author(s) (or their employer(s)) 2020. Re-use permitted under CC BY-NC. No commercial re-use. See rights and permissions. Published by BMJ.

\section{D) Check for updates}

To cite Adami G, Benini C, Vantaggiato E, et al. Ann Rheum Dis 2020;79:1122-1123.

Received 9 February 2020

Revised 18 February 2020

Accepted 19 February 2020

Published Online First 26 February 2020

Ann Rheum Dis 2020;79:1122-1123. doi:10.1136/annrheumdis-2020-217119

\section{ORCID iDs}

Giovanni Adami http://orcid.org/0000-0002-8915-0755

Maurizio Rossini http://orcid.org/0000-0001-9692-2293

\section{REFERENCES}

1 Jagsi R, Guancial EA, Worobey CC, et al. The "gender gap" in authorship of academic medical literature--a 35-year perspective. N Engl J Med 2006;355:281-7.

2 Merman E, Pincus D, Bell C, et al. Differences in clinical practice guideline authorship by gender. Lancet 2018;392:1626-8.

3 Filardo G, da Graca B, Sass DM, et al. Trends and comparison of female first authorship in high impact medical journals: observational study (1994-2014). BMJ 2016;352:i847. 